The $4^{\text {th }}$ Conf. of SSFOP “Ornamental Plants and Environment”, Cairo, Egypt, 22/4/2018

Scientific J. Flowers \& Ornamental Plants

www.ssfop.com/journal

ISSN: 2356-7864

doi: $10.21608 /$ sjfop.2018.18128

\title{
EFFECT OF SOME FERTILIZATION TREATMENTS ON GROWTH, PRODUCTIVITY AND CHEMICAL CONSTITUENTS OF ROSELLE (HIBISCUS SABDARIFFA L.). PLANTS
}

\author{
A.O. Gomaa, A.S.M. Youssef, Y.F.Y. Mohamed and Mai S.A. AbdAllah \\ Horticulture Department, Faculty of Agriculture, Benha University, Egypt.
}

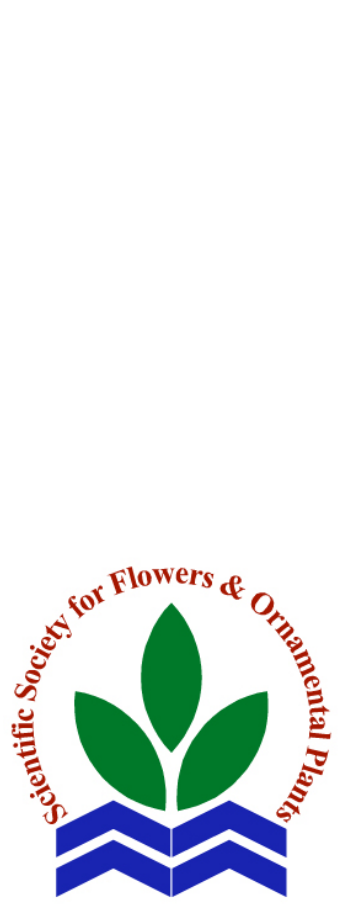

ABSTRACT: A field experiment was conducted during 2015 and 2016 seasons at the Experimental Farm, Horticulture Dept., Fac. Agric., Benha Univ. to evaluate the effect of some fertilization treatments [10, 20 and 30 $\mathrm{m}^{3}$ compost/fed + bio fertilizer (nitrobein + phosphorein + potassiumag)] when compared with the recommended dose of chemical fertilizer in the presence of micro-nutrients $\mathrm{Fe}+\mathrm{Mn}+\mathrm{Zn}$ foliar spraying (0.0, 50, 100 and $150 \mathrm{ppm}$ ) as well as their interaction between them on some growth parameters, yield and chemical constituents of roselle (Hibiscus sabdariffa L.) plants during 2015 and 2016 seasons.

In this respect, all applied fertilizer treatments statistically and positively affected each of plant height, number of leaves, branches and fruits/plant, fresh and dry weight of leaves, branches and sepals/plant, sepals anthocyanin and vitamin-C content, leaf $\mathrm{N}, \mathrm{P}, \mathrm{K}$, total carbohydrates, $\mathrm{Fe}, \mathrm{Zn}$ and $\mathrm{Mn}$ content and total indoles but they decreased the values of total phenols contents, especially $\mathrm{T}_{2}$ treatment (the recommended dose of chemical fertilizer) or $30 \mathrm{~m}^{3}$ compost/fed + bio fertilizer (nitrobein + phosphorein + potassiumag), with the exception of sepals acidity with none significant differences in the two seasons. Also, all concentrations of micro-nutrients $\mathrm{Fe}+\mathrm{Mn}+\mathrm{Zn}$ significantly improved all the aforementioned parameters, especially using the high rates.

Scientific J. Flowers \& Additionally, the highest values of plant height, number of leaves and Ornamental Plants, 5(2):171-193 (2018). branches/plant, fresh and dry weight of leaves and branches/plant, number of fruits/plant, seed yield/plant (g), leaf N, P, K, total carbohydrates, Fe,

Received:

$12 / 3 / 2018$

Accepted:

22/3/2018

$\mathrm{Zn}$ and $\mathrm{Mn}$ content, total indoles as well as the lowest values of total phenols contents were recorded by the combined treatment between $T_{2}$ recommended dose chemical fertilizer and 150ppm $\mathrm{Fe}+\mathrm{Mn}+\mathrm{Zn}$ acid in both seasons. Moreover, the combined treatment between $T_{5}\left(30 \mathrm{~m}^{3}\right)$ compost/fed + bio fertilizer and $150 \mathrm{ppm} \mathrm{Fe}+\mathrm{Mn}+\mathrm{Zn}$ gave the highest values of fresh and dry weight of sepals/plant sepals acidity, sepals anthocyanin and vitamin-C content of roselle plants as compared with control in both seasons. Furthermore, the combined treatments of $\mathrm{T}_{4}(20$ $\mathrm{m}^{3}$ ) compost/fed + bio fertilizer and $150 \mathrm{ppm} \mathrm{Fe}+\mathrm{Mn}+\mathrm{Zn}$ induced high significant increments in this concern in the two seasons.

Consequently, it is preferable to treat roselle plants with the combined treatment between $T_{2}$ (recommended dose of chemical fertilizer) or $T_{5}$ (30 $\mathrm{m}^{3}$ ) compost/fed + bio fertilizer (nitrobein + phosphorein + potassiumag) and $\mathrm{Fe}+\mathrm{Mn}+\mathrm{Zn}$ at $150 \mathrm{ppm}$ for enhancing growth and productivity of this plants.

Key words: Roselle, chemical \& organic fertilization, micro-nutrients, growth, yield, anthocyanin, chemical composition. 


\section{A.O. Gomaa et al.}

\section{INTRODUCTION}

Hibiscus sabdariffa L. (Roselle) is one of the most important plants of the Malvaceae Family. The plant is indigenous to tropic Africa (Kirby, 1963). Roselle is a folk remedy for abscesses, bilious conditions, cancer, cough, debility, dyspepsia, fever. Leaves are emollient and sedative. Fruits are scorbutic. The succulent calyx boiled in water is said to be a folk remedy for cancer (Duke, 1979), flowers contain gossyperin, anthocyanin and glycol side hibiscin, which may have diuretic and choleretic effects, decreasing the viscosity of the blood, reducing blood pressure and stimulating intestinal peristalsis (Perry, 1980 and Sanyo, 1981 and Hassan, 2009). It has antimicrobial activities due to its phenolic compounds. It contains protein, fibers, calcium, iron, carotenes and vitamin C (Fasoyiro et al., 2005).

Recently, unconventional efforts are used to minimize the amounts of chemical fertilizers which applied to medicinal and aromatic plants in order to reduce production cost and environmental pollution without reduction of yield. Therefore, the trend now is using the bio and organic fertilizers. Bio fertilizers can influence plant growth directly through the production of phytohormones such as gibberellins, cytokinins and IAA that act as growth regulators and indirectly through nitrogen fixation and production of bio-control agents against soil-borne phytopathogens and consequently increase formation of metabolites which encourage the plant vegetative growth and enhance the meristematic activity of tissues to produce more growth (Glick, 2003 and Ahmed and Kibret, 2014). Organic fertilizers are obtained from animal sources such as animal manure or plant sources like green manure. Continuous usage of inorganic fertilizer affects soil structure. Hence, organic manures can serve as alternative to mineral fertilizers for improving soil structure (Shahram and Ordookhani, 2011) and microbial biomass (Suresh et al., 2004). The addition of organic fertilizers to agricultural soils has beneficial effects on crop development and yields by improving soil physical and biological properties (Zheljazkov and Warman, 2004). Organic and bio fertilizers in comparison to the chemical fertilizers have lower nutrient content and are slow release but they are as effective as chemical fertilizers over longer periods of use (Naguib, 2011 and Mohamed et al., 2012).

Moreover, activates micro-nutrients, especially Fe, $\mathrm{Zn}$ and $\mathrm{Mn}$ which act either as metal components of various enzymes or as functional, structural, or regulatory cofactors. Thus, they are associated with saccharide metabolism, photo-synthesis and protein synthesis Marschner, (1997).

Many investigators reported the stimulating effect of applied micronutrients as foliar spray on growth and flowering of different medicinal and aromatic plants. In this respect El-Khyat (2013) on Rosmarinus officinalis, Amran (2013) on Pelargonium graveolens, Youssef (2014) on Echinacea purpurea and Ghatas and Mohamed (2018) illustrated that, spray Cymbopgon citruts plants $150 \mathrm{ppm} \mathrm{Fe}+\mathrm{Mn}+\mathrm{Zn}$ four times a year to enhance the growth, essential oil yield and constituents and some chemical constituents of this plant.

Therefore, the purpose of this study was to evaluate the benefits of supplementing organic in the form of compost manure and bio fertilizers in the presence of micronutrients $\mathrm{Fe}+\mathrm{Mn}+\mathrm{Zn}$ on growth and yield of roselle plants and to minimize consuming chemical fertilizers.

\section{MATERIALS AND METHODS}

This work was carried out at the Experimental Farm, Fac. Agric., Moshtohor Benha Univ. during 2015 and 2016 seasons to study the effect of some fertilization treatments $\left(10,20\right.$ and $30 \mathrm{~m}^{3}$ compost/fed + bio fertilizer (nitrobein + phosphorein + potassiumag)) when compared with recommended dose of chemical fertilizer in presence of micro-nutrients $\mathrm{Fe}+\mathrm{Mn}+\mathrm{Zn}$ foliar spraying $(0.0,50,100$ and $150 \mathrm{ppm})$ as 
well as their interaction between them on some growth parameters, yield and chemical constituents of roselle (Hibiscus sabdariffa L.) plants during 2015 and 2016 seasons. Roselle seeds were obtained from Floriculture Farm, Horticulture Department, Faculty of Agriculture, Benha Univ. Seeds were sown in clay loam soils on mid-April of each seasons in plots $(1 \times 1 \mathrm{~m})$ containing two rows (50 $\mathrm{cm}$ width) every row had two hills (50 cm apart), and one month later, the plants were thinned, leaving only one seedling/hill.

Physical and chemical analyses of the experimental soil were determined according to Jackson (1973) and Black et al. (1982), respectively. The obtained results of soil analyses are presented in Table (1).

This experiment was set up in a split plot design with three replicates. The main plot was employed by five fertilization treatments i.e. $\mathrm{T}_{1}$ (control), $\mathrm{T}_{2}$ recommended chemical fertilization dose; $100 \mathrm{~kg} / \mathrm{fed}$ ammonium nitrate $(33.5 \% \mathrm{~N})+300 \mathrm{~kg} /$ fed calcium super phosphate $\left(15.5 \% \mathrm{P}_{2} \mathrm{O}_{5}\right)+150 \mathrm{~kg} / \mathrm{fed}$ potassium sulphate $\left(48 \% \mathrm{~K}_{2} \mathrm{O}\right)$ according to the Egyptian Ministry of Agriculture and Land Reclamation (2002), organic fertilizer (compost (containing plant sources and cattle manure; $\mathrm{T}_{3}\left(10 \mathrm{~m}^{3}\right)$ compost/fed + bio fertilizer (nitrobein + phosphorein + potassiumag), $\mathrm{T}_{4}\left(20 \mathrm{~m}^{3}\right)$ compost/fed + bio fertilizer, $T_{5}\left(30 \mathrm{~m}^{3}\right)$ compost/fed + bio fertilizer the chemical properties of the tested compost are presented in Table (2) Whereas, the sub plot was devoted to four of micronutrients $\mathrm{Fe}+\mathrm{Mn}+\mathrm{Zn}$ sprays i.e., control (tap water), 50, 100 and $150 \mathrm{ppm}$. The amount of $\mathrm{N}$ and $\mathrm{K}$ fertilizers were divided into three equal portions as side dressing and added at three dates on 15 June, 15 July and 15 August, respectively of both seasons. However, the amount of P-fertilizer and compost were added to the soil before seed sowing during soil preparation. Micronutrients $\mathrm{Fe}+\mathrm{Mn}+\mathrm{Zn}$ treatments were applied as foliar spray at 60, 90 and 120 days after planting, respectively.

The bio-fertilizer used were nitrobein (Azotobacter chroococcum) for nitrogein fixation), phosphorus solublizing bacteria; e.i., (Bacillus megatherium) phosphorein and potassiumag (active Bacillus $s p$ ). Which supplied by the Department of Microbiology, Agric. Res. Center, Giza was used in this study as biological activators. The strains were characterized by a good ability to infect its specific host plant and by its high efficiency in N-fixation, phosphate and potassium solublizing.

Table 1. Mechanical properties and chemical analysis of the experimental soil in the two seasons.

\begin{tabular}{|c|c|c|c|c|c|}
\hline \multirow{3}{*}{$\begin{array}{r}\text { Parameters } \\
\text { M }\end{array}$} & \multicolumn{2}{|c|}{ Values } & Parameters & \multicolumn{2}{|c|}{ Values } \\
\hline & \multicolumn{2}{|c|}{ Mechanical properties } & \multicolumn{3}{|c|}{ Chemical analysis } \\
\hline & (2015) & (2016) & & (2015) & (2016) \\
\hline Coarse sand & $3.22 \%$ & $3.75 \%$ & Organic matter & $1.55 \%$ & $1.68 \%$ \\
\hline Fine sand & $15.40 \%$ & $13.95 \%$ & $\mathrm{CaCO}_{3}$ & $0.95 \%$ & $1.05 \%$ \\
\hline Silt & $26.20 \%$ & $25.80 \%$ & Available nitrogen & $0.55 \%$ & $0.62 \%$ \\
\hline Clay & $55.18 \%$ & $56.50 \%$ & Available phosphorus & $0.26 \%$ & $0.22 \%$ \\
\hline \multirow[t]{3}{*}{ Textural class } & Clay loam & Clay loam & Available potassium & $0.34 \%$ & $0.37 \%$ \\
\hline & & & pH & 7.62 & 7.67 \\
\hline & & & EC (dS/m) & 0.73 & 0.81 \\
\hline
\end{tabular}

Table 2. Chemical properties of the used compost.

\begin{tabular}{|c|c|c|c|c|c|c|c|c|c|c|}
\hline Parameters & $\begin{array}{c}\text { Ec dS. } \mathrm{m}^{-1} \\
\quad(1: 5)\end{array}$ & $\underset{(1: 5)}{\text { pH }}$ & $\begin{array}{l}\text { Total } \\
\text { C \% }\end{array}$ & $\begin{array}{l}\text { Total } \\
\text { N \% }\end{array}$ & $\begin{array}{l}\text { Total } \\
\text { P \% }\end{array}$ & $\begin{array}{l}\text { Total } \\
\text { K \% }\end{array}$ & $\begin{array}{c}\text { Total Fe } \\
\text { (ppm) }\end{array}$ & $\begin{array}{c}\text { Total Zn } \\
\text { (ppm) }\end{array}$ & $\begin{array}{c}\text { Total Mn } \\
\text { (ppm) }\end{array}$ & $\begin{array}{c}\mathrm{C}: \mathrm{N} \\
\text { ratio }\end{array}$ \\
\hline Values & 2.33 & 6.72 & 21.88 & 1.42 & 0.36 & 1.24 & 1378 & 245 & 212 & $15: 1$ \\
\hline
\end{tabular}




\section{A.O. Gomaa et al.}

The seeds of roselle were washed with water, thereafter the seeds were soaked in cell suspension of the mixture of nitrobein, phosphorein and potassiumag ( $1 \mathrm{ml}$ contains 108 viable cell) for $30 \mathrm{~min}$. Gum arabic (16 $\%)$ was added as an adhesive agent prior to soaking the seeds. The inoculated seeds were air dried at room temperature for one hour before planting. Another two applications were applied (1 kg/fed) as an aqueous solution, the first one was applied just before irrigation after 60 days from planting date, whereas the second one was done after 90 days from planting date to increase the power ability of bacteria.

\section{Recorded data:}

\section{Plant growth:}

Plant height $(\mathrm{cm})$, number, fresh and dry weight of leaves (g) number, fresh and dry weight of branches (g) were taken at the beginning of flowering stage; September 2015 and 2016.

\section{Fruits yield:}

Number of fruits /plant, sepals fresh and dry weights/plant, seed yield/plant, were recorded at harvesting time (November 2015 and 2016).

\section{Chemical constituents:}

At harvesting time anthocyanin content was determined in air-dried roselle sepals according to the method described by Du and Francis (1973). Vitamin-C was determined in sepals as discribed in A.O.A.C. (1980). Sepals acidity (pH value) was determined according to Diab (1968). The percentage of $\mathrm{N}, \mathrm{P}, \mathrm{K}$ and total carbohydrates \% were determined in the dry leaves during flowering stage, by Horneck and Miller (1998), Hucker and Catroux (1980), Horneck and Hanson (1998) and Herbert et al. (1971), respectively. Where total indoles and total phenols were determined in roselle fresh leaves according to A.O.A.C (1990). In addition, micronutrients $\mathrm{Fe}, \mathrm{Zn}$, and $\mathrm{Mn}$ (\%) were determined in the digested samples by atomic absorption as described by Chapman and Paratt (1961).

\section{Statistical analysis:}

All data obtained in both seasons of study were subjected to analysis of variance as factorial experiments in split plot design. L.S.D. method was used to differentiate means according to Snedecor and Cochran (1989).

\section{RESULTS AND DISCUSSION}

\section{Vegetative growth parameters:}

\section{Plant height $(\mathrm{cm})$ and No. of leaves/plant:}

Data presented in Table (3) indicate that, all studied fertilization treatments succeeded in increasing plant height and No. of leaves/plant of roselle (Hibiscus sabdariffa L.) plants in both seasons. However, the tallest plant and the highest No. of leaves/plant were achieved by $\mathrm{T}_{2}$ (R.D. chemical NPK) followed by $T_{5}\left(30 \mathrm{~m}^{3}\right.$ compost/fed + bio) in the first and second seasons.

As for micro-nutrients treatments, data in the same Table indicate that there was appositive relationship between the values of these parameters and micro-nutrients concentration, hence as the concentration of micro-nutrients increased the values of plant height and No. of leaves/plant increased till reach to the highest increases at the highest concentration (150 ppm) in the two seasons.

Regarding the interaction effect between fertilization and micro-nutrients treatments data in Table (3) show that all resulted combinations increased the plant height and No. of leaves/plant of roselle plants with significant differences in most cases as compared with control plants in the two seasons of this study. However, the combination of $\mathrm{T}_{2}$ (R.D. chemical NPK) showed to be the most effective ones for inducing the highest values of plant height and No. of leaves/plant especially those sprayed with micro-nutrients the highest concentration (150 ppm) as it scored (186.2 


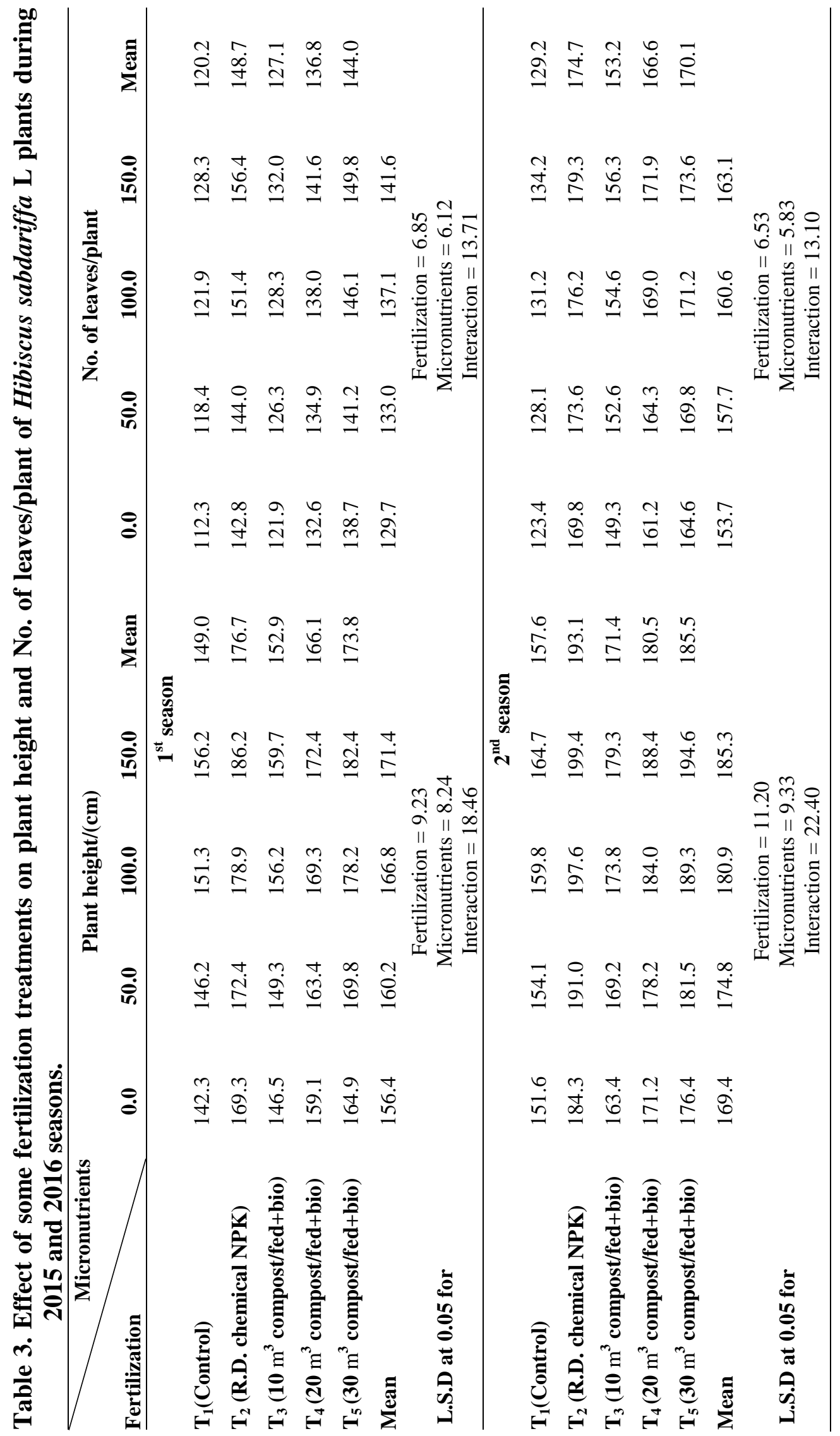




\section{A.O. Gomaa et al.}

and $199.4 \mathrm{~cm}$ ) and (156.4 and $179.3 \mathrm{~cm})$ in the first and second seasons, respectively. Moreover, the combination of $\mathrm{T}_{5}\left(30 \mathrm{~m}^{3}\right.$ compost/fed + bio) resulted in high increments in this concern particularly those received micro-nutrients at $150 \mathrm{ppm}$ in both seasons. Irrespective control, the lowest values of this parameter were gained by $\mathrm{T}_{3}$ (10 $\mathrm{m}^{3}$ compost/fed + bio) combination, especially those received no micro-nutrients sprays in the two seasons. The remained treatments occupied an intermediate position between the abovementioned treatments in the two seasons.

\section{Leaves fresh and dry weights/plant (g):}

Data in Table (4) reveals that fresh and dry weights of leaves per plant were positively affected by all fertilization and micro-nutrients treatments in both seasons. However, the heaviest fresh and dry weights of leaves per plant of roselle plants were recorded by $\mathrm{T}_{2}$ (R.D. chemical NPK) followed by $\mathrm{T}_{5}\left(30 \mathrm{~m}^{3}\right.$ compost/fed + bio $)$ in the first and second seasons.

Moreover, all treatments of micronutrients statistically increased the fresh and dry weights of leaves per plant, especially the highest concentration (150 ppm) in both seasons.

As for the interaction effect between fertilization and micro-nutrients treatments, it was observed that, the heaviest fresh and dry weights of leaves per plant in the first and second seasons were recorded by the combined treatment between $\mathrm{T}_{2}$ (R.D. chemical NPK) with micro-nutrients at $150 \mathrm{ppm}$, in both seasons. Furthermore, the combination of $\mathrm{T}_{2}$ (R.D. chemical NPK) with micro-nutrients at $100 \mathrm{ppm}$ or $\mathrm{T}_{5}\left(30 \mathrm{~m}^{3}\right.$ compost/fed + bio) with micro-nutrients at $150 \mathrm{ppm}$ ranked the second and third values of these parameters in this concern in the first and second seasons, respectively. Regardless control, the lowest values of these parameters were gained by combination treatment between $T_{3}\left(10 \mathrm{~m}^{3}\right.$ compost/fed + bio) with 0.0 ppm micronutrients sprays in the two seasons.

\section{No. of branches/plant, branches fresh and dry weights/plant (g):}

Data in Table (5) illustrated that No. of branches per plant, fresh and dry weights of branches per plant were positively affected by all fertilization in both seasons. However, the highest values of these parameters of roselle plants were recorded by $\mathrm{T}_{2}$ (R.D. chemical NPK) followed by $T_{5}\left(30 \mathrm{~m}^{3}\right.$ compost/fed + bio) in the first and second seasons. On the other side, the lowest values of these parameters were scored by control plants in both seasons.

Moreover, all treatments of micronutrients statistically increased No. of branches per plant, fresh and dry weights of branches per plant, especially the highest concentration (150 ppm) in both seasons.

As for the interaction effect between fertilization and micro-nutrients treatments data in Table (5) reveals that, the highest values of these parameters were recorded by the combined treatment between $\mathrm{T}_{2}$ (R.D. chemical NPK) with micro-nutrients at 150 ppm, followed descendingly by the combined treatment between $T_{5}\left(30 \mathrm{~m}^{3}\right.$ compost/fed + bio) with micro-nutrients at $150 \mathrm{ppm}$ in both seasons.

The aforementioned results of tested fertilization treatment are in agreement with those obtained by Abou El-Ghait et al. (2012) on Indian fennel, El-Gendy et al. (2012) on roselle plants, Mohamed et al. (2012) on Stevia rebaudiana, Amran (2013) on Pelargonium graveolens, El-Khyat (2013) on Rosmarinus officinalis, El-Gendy et al. (2013) on guar plants, Sakr et al. (2014) on roselle plants, Youssef (2014) on roselle plants and Ghatas and Abdallah (2016) illustrated that, fertilize Echinacea purpurea plants with $75 \%$ chemical fertilizer $(\mathrm{NPK})+10$ ton compost/fed + bio fertilizer (nitrobein + phosphorein) in combination with some micro-nutrients ( $\mathrm{Zn}$ or B each at $100 \mathrm{ppm}$ ) as foliar spray to enhance the vegetative growth of plant. Whereas, the abovementioned results of micro-nutrients are nearly similar to those obtained by 


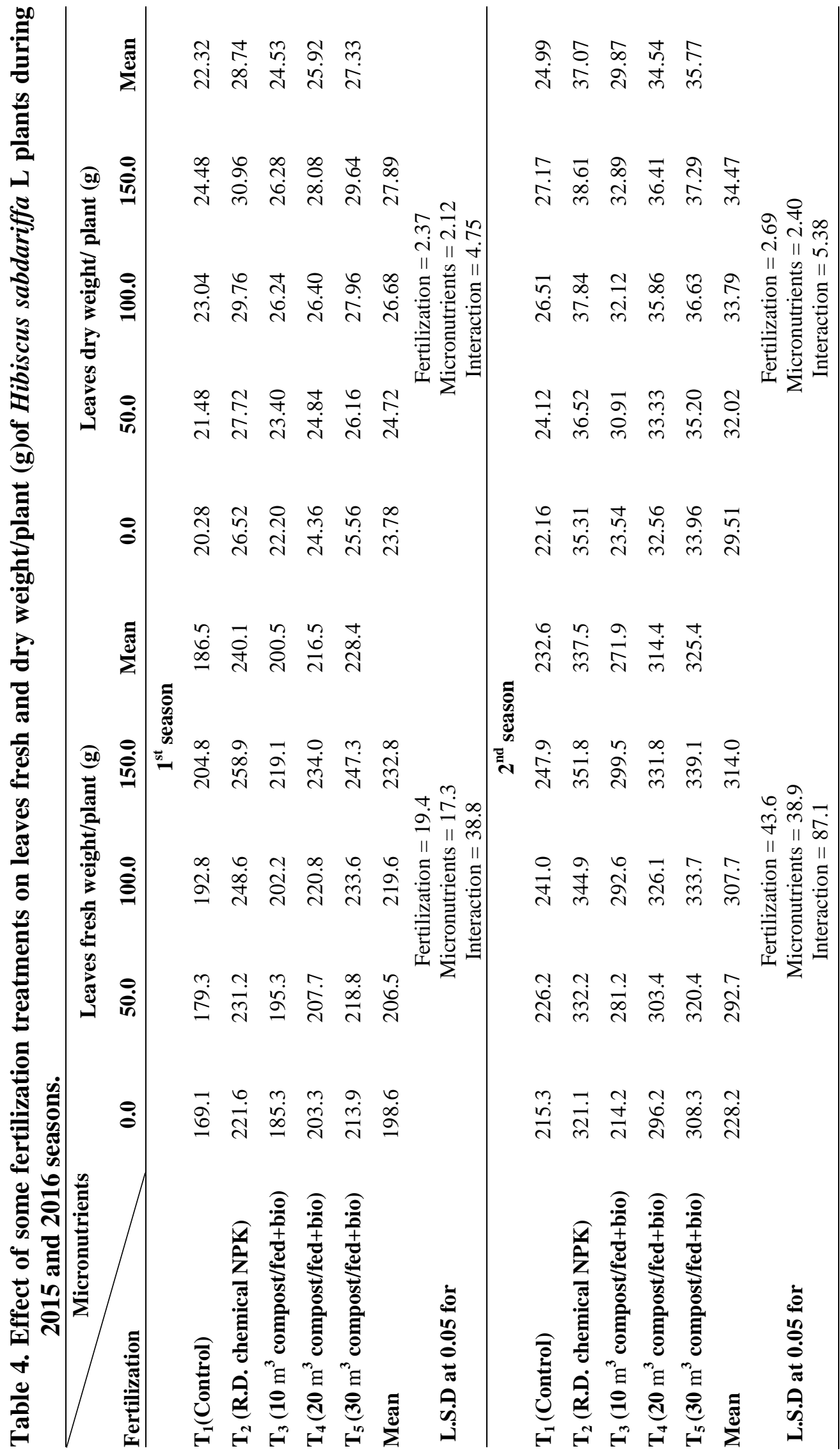




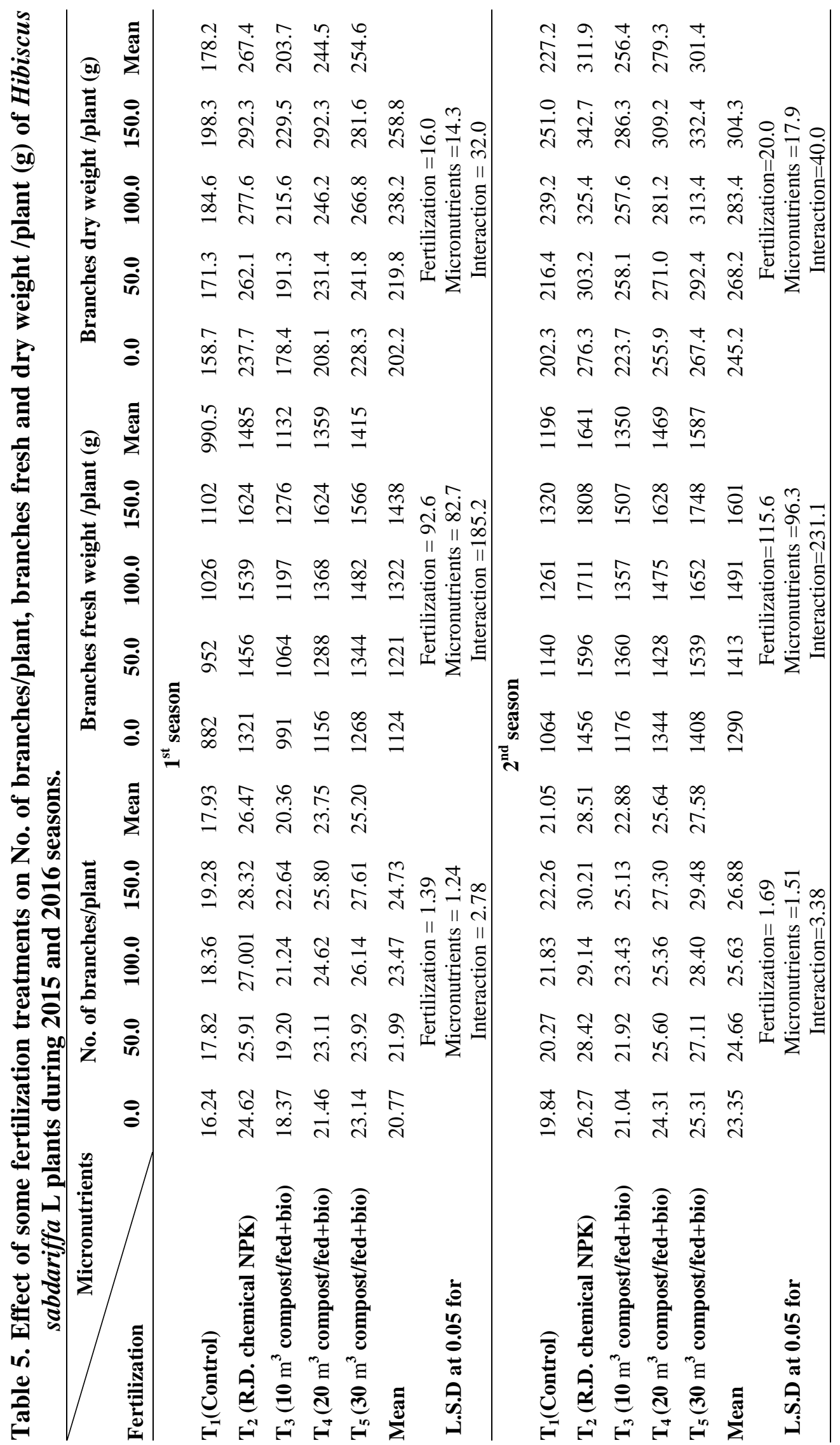


Gomaa (2008) on Hibiscus sabdariffa, Youssef (2009) on rosemary plant, Amran (2013) on Pelargonium graveolens, ElKhyat (2013) on Rosmarinus officinalis, Youssef (2014) on Echinacea purpurea, and Ghatas and Mohamed (2018) demonstrated that, spray Cymbopgon citruts plants with $150 \mathrm{ppm} \mathrm{Fe}+\mathrm{Mn}+\mathrm{Zn}$ four times a year to enhance the vegetative growth of this plant.

\section{Yield parameters:}

\section{No. of fruits/plant and seed yield/plant (g):}

Data in Table (6) reveal that the highest No. of fruits/plant and seed yield/plant (g) were scored by $\mathrm{T}_{2}$ (R.D. chemical NPK) treatment, followed by $\mathrm{T}_{5}\left(30 \mathrm{~m}^{3}\right.$ compost/fed + bio) treatment in the first and second seasons.

Also, No. of fruits/plant and seed yield/plant (g) were greatly affected by spraying roselle plants with micro-nutrients treatments, particularly the highest concentration (150 ppm) as compared with unsprayed plants in the two seasons.

As for the interaction effect between fertilization and micro-nutrients treatments, data in Table (6) show that all resulted combinations increased these parameters in the two seasons. However, the highest No. of fruits/plant was recorded by the combined treatments between $\mathrm{T}_{5}$ (30-ton compost/fed + bio) with micro-nutrients at $150 \mathrm{ppm}$ as it scored (71.3 and 78.1) followed descendingly by $T_{2}$ (R.D. chemical NPK) with micro-nutrients at $150 \mathrm{ppm}$ as it scored (71.2 and 77.6) in the first and second seasons, respectively. whereas, the highest seed yield/plant was obtained by $T_{2}$ treatment combined with micro-nutrients at $150 \mathrm{ppm}$ as it scored (54.66 and 56.70), followed by the combined treatment between $\mathrm{T}_{5}$ and micro-nutrients at $150 \mathrm{ppm}$ as it scored (54.20 and 56.12) in the first and second seasons, respectively. The differences between the abovementioned two combined treatments were not-significance in both seasons. The lowest values of this parameter were gained by combination treatment between $T_{1}$ (control) with 0.0 ppm micronutrients sprays in the two seasons.

\section{Fresh and dry weights of sepals/plant:}

It is clear from data in Table (7) that the heaviest fresh and dry weights of sepals/plant of roselle (Hibiscus sabdariffa L.) plants were recorded by $\mathrm{T}_{5}\left(30 \mathrm{~m}^{3}\right.$ compost/fed + bio) followed descendingly by $\mathrm{T}_{4}$ (20-ton compost/fed) in both seasons.

In addition, using the treatment $\mathrm{T}_{2}$ (R.D. chemical NPK) ranked the third values of these parameters in the two seasons Remarkably, all concentrations of micronutrients resulted in significant increments in these parameters, especially those received the highest concentration (150 ppm) as compared with un-treated plants in the two seasons. Generally, all resulted interactions between fertilization and micro-nutrients treatments statistically affected the fresh and dry weights of sepals/plant in both seasons.

However, the heaviest fresh and dry weights of sepals/plant were gained by using the combined treatments between $T_{5}\left(30 \mathrm{~m}^{3}\right.$ compost/fed + bio) with micro-nutrients at $150 \mathrm{ppm}$ followed descendingly by $\mathrm{T}_{4}$ (20ton compost/fed) with micro-nutrients at 150 ppm in both seasons. Moreover, the combination of $\mathrm{T}_{2}$ (R.D. chemical NPK) resulted in high increments in this concern especially those received the highest concentration of micro-nutrients at $150 \mathrm{ppm}$ in the two seasons.

These results are in close agreement with those reported by Sakr et al. (2014) on roselle plants and Youssef (2014) on roselle plant.

\section{Chemical constituents:}

\section{Anthocyanin content:}

Data in Table (8) show that the highest anthocyanin content of roselle (Hibiscus sabdariffa L.) plants (172.7 and 160.1 $\mathrm{mg} / 100 \mathrm{~g} \mathrm{~d}$.w.) was accumulated in sepals as a result of using $T_{5}\left(30 \mathrm{~m}^{3}\right.$ compost/fed + bio) treatment, followed descendingly by $\mathrm{T}_{2}$ (R.D. chemical NPK) as it recorded (169.6 and $158.3 \mathrm{mg} / 100 \mathrm{~g}$ d.w.) in the first and 


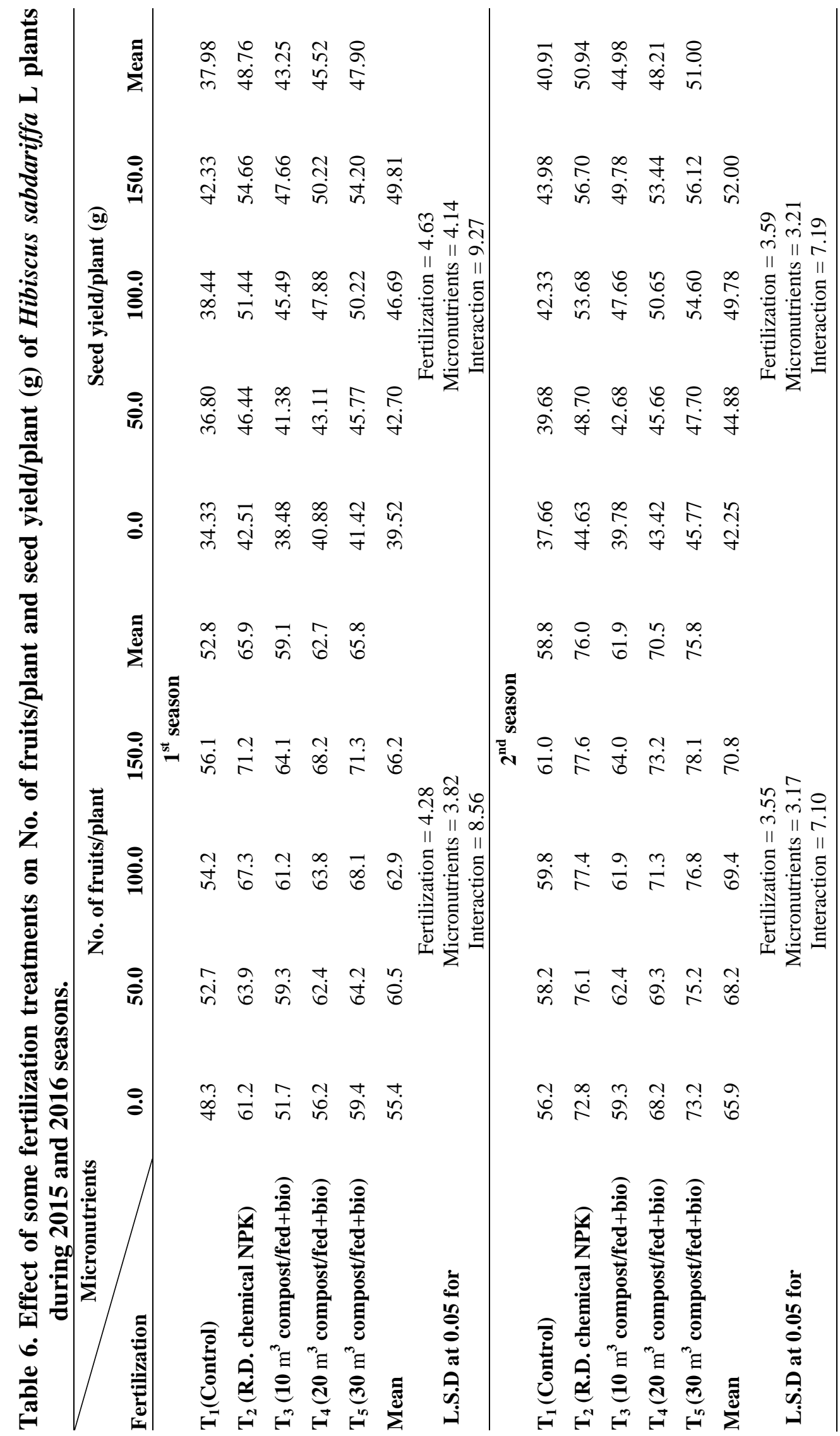




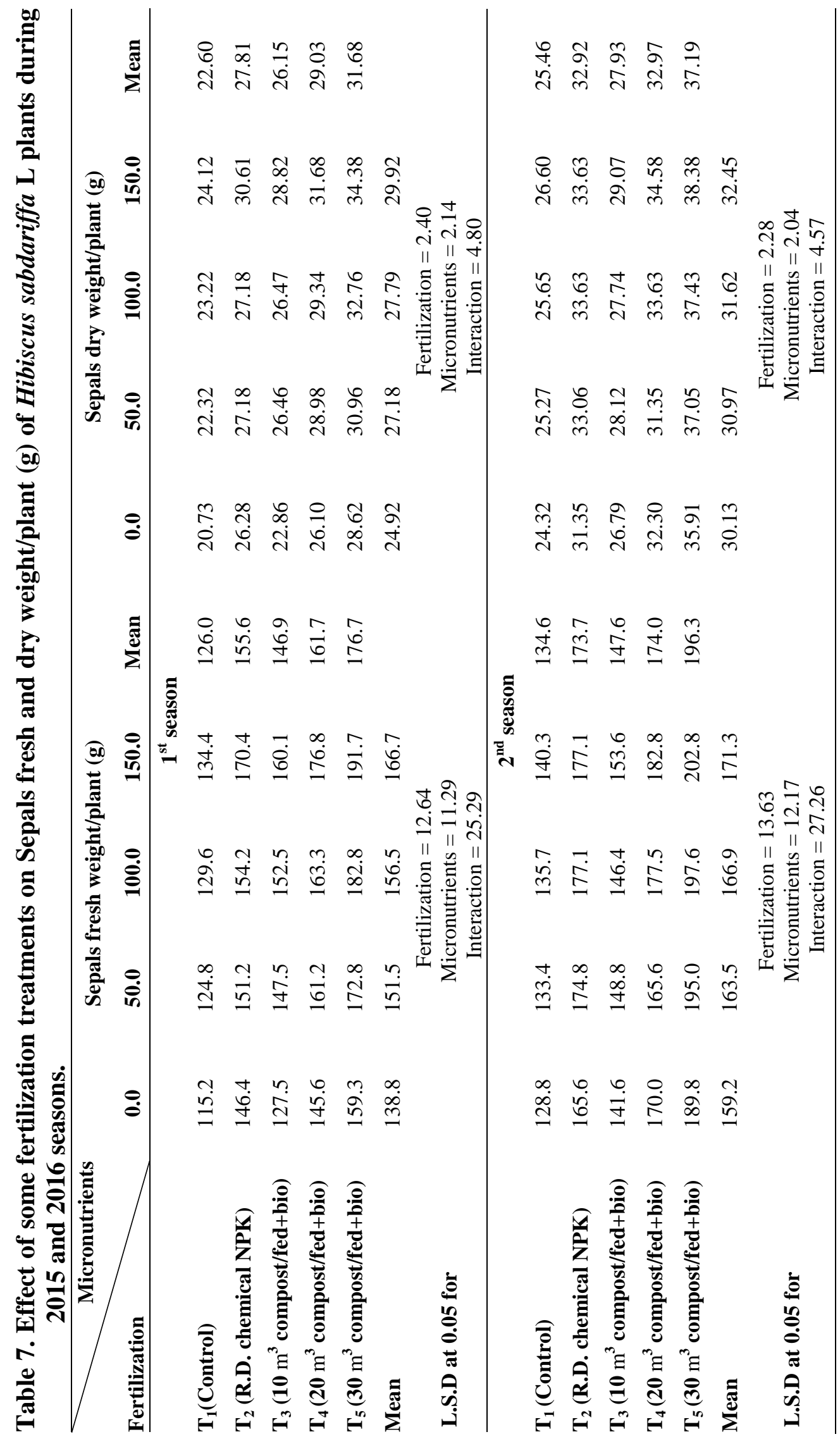




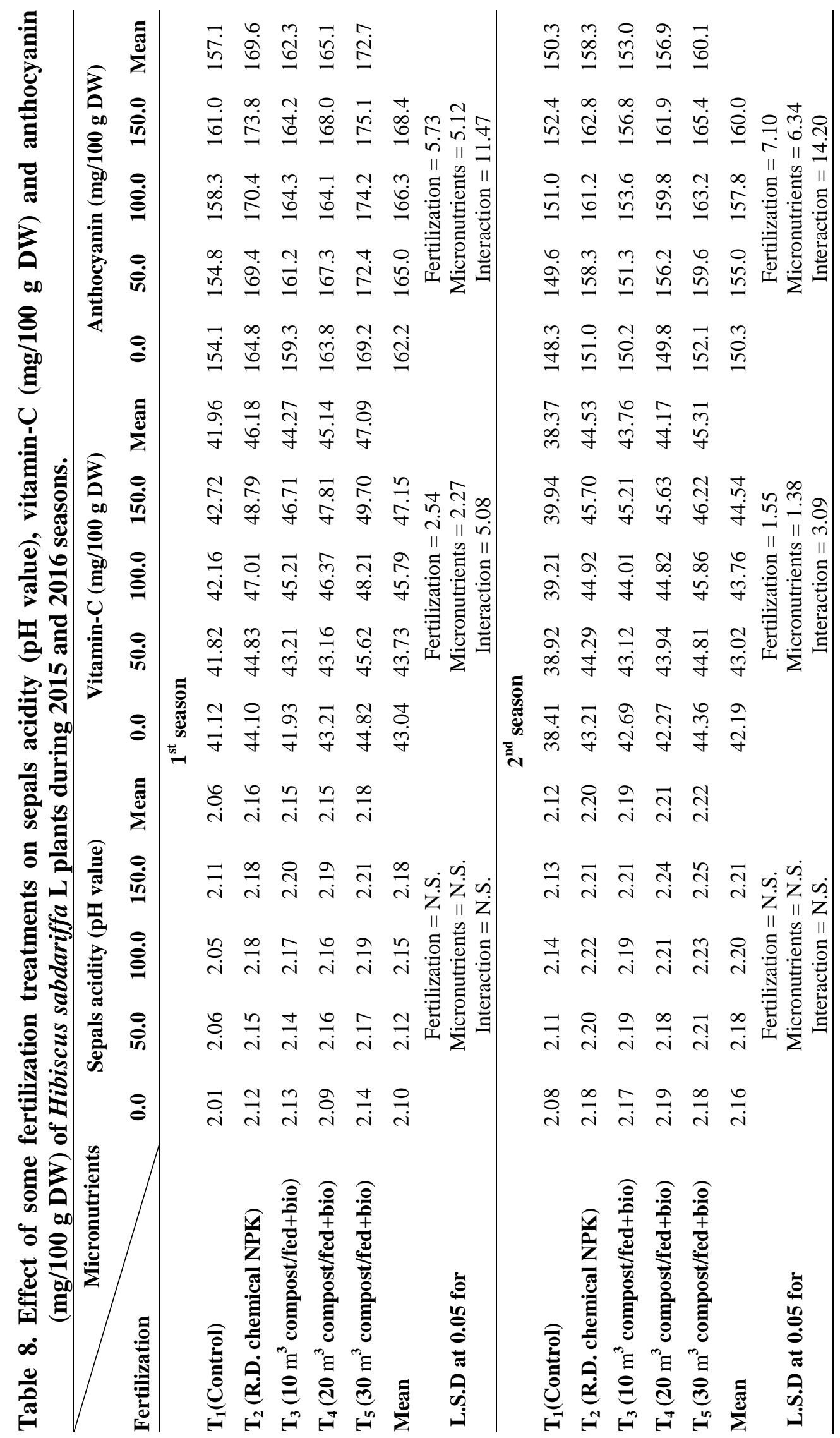


second seasons, respectively with nonsignificant differences between them.

Additionally, all concentration of micronutrients succeeded in increasing anthocyanin content of roselle sepals, especially highest concentration (150 ppm) in both seasons.

Generally, $\mathrm{T}_{5}\left(30 \mathrm{~m}^{3}\right.$ compost/fed + bio) treatment combined with micro-nutrients at $150 \mathrm{ppm}$ gave the highest values in this concern (175.1 and $165.4 \mathrm{mg} / 100 \mathrm{~g}$ d.w.) in the first and second seasons, respectively), followed by the combined treatment between $\mathrm{T}_{5}$ (30 $\mathrm{m}^{3}$ compost/fed + bio) treatment and micro-nutrients at $100 \mathrm{ppm}$ (174.2 and 163.2 $\mathrm{mg} / 100 \mathrm{~g}$ d.w., in the first and second seasons, respectively). Also, the combined treatment between $\mathrm{T}_{2}$ (R.D. chemical NPK) with micro-nutrients at $150 \mathrm{ppm}$ ranked the third values in this concern as it resulted (173.8 and $162.8 \mathrm{mg} / 100 \mathrm{~g} \mathrm{d.w.,} \mathrm{in} \mathrm{the} \mathrm{first}$ and second seasons, respectively). On the reverse, the lowest values of this parameter were recorded by combination treatment between $\mathrm{T}_{1}$ (control) with $0.0 \mathrm{ppm}$ micronutrients sprays as it recorded (154.1 and $148.3 \mathrm{mg} / 100 \mathrm{~g}$ d.w. ) in the first and second seasons, respectively.

\section{Vitamin C:}

Data in Table (8) indicate that the highest content of vitamin C (47.09 and $45.31 \mathrm{mg} / 100 \mathrm{~g}$ d.w.) was recorded by $\mathrm{T}_{5}$ (30 $\mathrm{m}^{3}$ compost/fed + bio), followed by $\mathrm{T}_{2}$ (R.D. chemical NPK) (46.18 and 44.53 mg/100 g d.w.) and $\mathrm{T}_{4}\left(20 \mathrm{~m}^{3}\right.$ compost/fed $)$ treatments (45.14 and $44.17 \mathrm{mg} / 100 \mathrm{~g} \mathrm{d.w.)}$ in the first and second seasons, respectively.

Moreover, all concentration of micronutrients resulted increments of this parameter especially the highest concentration (150 ppm) as compared with untreated plants in both seasons.

Generally, $\mathrm{T}_{5}$ (30-ton compost/fed + bio) treatment combined with micro-nutrients at $150 \mathrm{ppm}$ showed to be the most effective one for inducing the highest sepals vitamin-C content (49.70 and $46.22 \mathrm{mg} / 100 \mathrm{~g}$ d.w., in the first and second seasons, respectively).
Also, the treatment of $T_{2}$ (R.D. chemical NPK) combined with micro-nutrients at 150 ppm or the combination treatment between $\mathrm{T}_{5}$ (30 $\mathrm{m}^{3}$ compost/fed + bio) with micronutrients at $100 \mathrm{ppm}$ resulted highly increases of this parameter as compared with control in the two seasons.

\section{Sepals acidity (pH value):}

Data in Table (8) illustrated that all tested fertilization and micro-nutrients treatments as well as their interactions resulted in negligible effects in this parameter with non-significant difference in both seasons. In general, the highest $\mathrm{pH}$ value (2.21 and 2.25) was recorded by $\mathrm{T}_{5}$ (30 $\mathrm{m}^{3}$ compost/fed + bio) treatment combined with micro-nutrients at $150 \mathrm{ppm}$ in the first and second seasons, respectively. On the reverse, the lowest values of this parameter were recorded by combination treatment between $\mathrm{T}_{1}$ (control) with $0.0 \mathrm{ppm}$ micronutrients sprays as it recorded (2.01 and 2.08) in the first and second seasons, respectively. The remained treatments occupied an intermediate position between the abovementioned treatments in the two seasons.

\section{Leaf $N, P$ and $K$ content:}

Data presented in Tables (9 and 10) declare that the highest values of leaf $\mathrm{N}, \mathrm{P}$ and $\mathrm{K}$ content of roselle plants were recorded by $\mathrm{T}_{2}$ (R.D. chemical NPK), followed by T5(30 $\mathrm{m}^{3}$ compost/fed + bio)in the first and second seasons. On the reverse, the lowest values of this parameter were scored by $T_{1}$ (control) treatment in the two seasons. Also, all micro-nutrients concentration sprays increased leaf $\mathrm{N}, \mathrm{P}$ and $\mathrm{K}$, especially the highest concentration of micro-nutrients (150 ppm) in both seasons. As for the interaction effect between fertilization and micronutrients treatments, data in Tables (9 and 10) reveal that the greatest leaf $N, P$ and $K$ of roselle plants were obtained by the combined treatment between $T_{2}$ (R.D. chemical NPK) and micro-nutrients at $150 \mathrm{ppm}$, followed by $\mathrm{T}_{5}$ treatment combined with micro-nutrients at $150 \mathrm{ppm}$ of both seasons in most cases. 


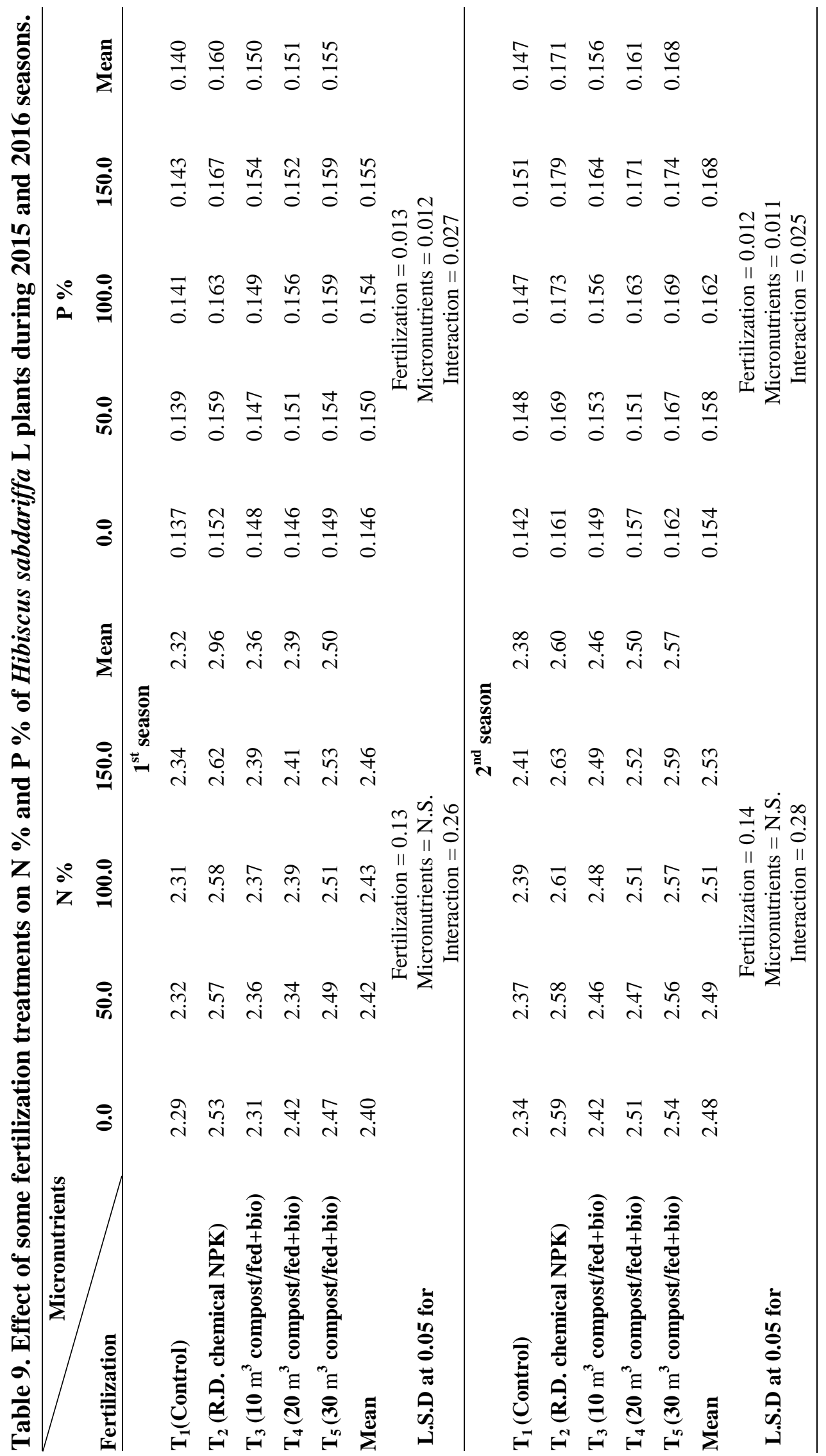




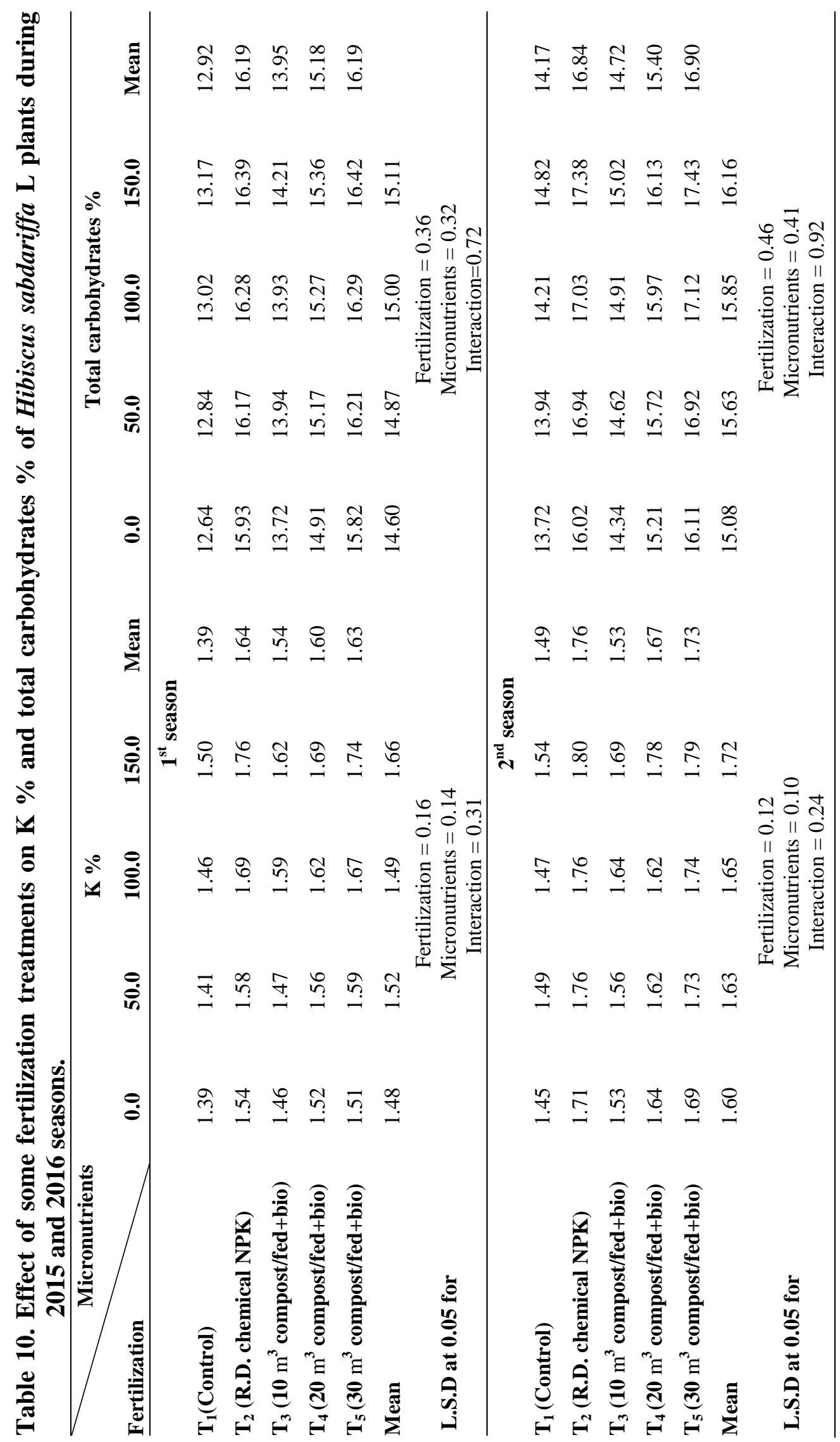




\section{A.O. Gomaa et al.}

\section{Leaf total carbohydrates contents:}

Data in Table (10) clear that there were significant differences in leaf total carbohydrates content as response to the studied fertilization treatments when compared with control in both seasons. Meanwhile, the highest values of this parameter were scored by $T_{5}\left(30 \mathrm{~m}^{3}\right.$ compost/fed + bio), followed by $\mathrm{T}_{2}$ (R.D. chemical NPK) in both seasons. The differences between the abovementioned two treatments were not-significance in both seasons.

With respect for the effect of micronutrients treatments, data in Table (10) show that all concentration of micro-nutrients (50, 100 and $150 \mathrm{ppm}$ ) resulted in significant increments in this parameter, with superiority for the highest concentration in both seasons.

As for the interaction effect between fertilization treatments and micro-nutrients treatments, data in Table (10) reveal that the highest values of total carbohydrates content (16.42 and $17.43 \%$ ) of roselle leaves were recorded by $\mathrm{T}_{5}$ treatment combined micronutrients at $150 \mathrm{ppm}$, followed by the combined treatment between $\mathrm{T}_{2}$ treatment combined micro-nutrients at $150 \mathrm{ppm}(16.39$ and $17.38 \%$ ), ,in the first and second seasons, respectively.

\section{Leaf total indoles contents:}

Data in Table (11) show that, all fertilization treatments resulted in an increment of total indoles in leaves of roselle plants when compared with control in both seasons. However, the highest values total indoles were registered by $\mathrm{T}_{2}$ treatment followed by $T_{5}$ in the two seasons. The differences between the abovementioned two treatments were non-significance in both seasons. Besides, all concentration of micronutrients treatments scored an increment in this parameter, with superiority for the highest concentration in both seasons. Furthermore, the highest values of total indoles content (284 and $287 \mathrm{mg} / 100 \mathrm{~g} \mathrm{f.w.)}$ of roselle leaves were recorded by $T_{2}$ treatment combined with micro-nutrients at 150 ppm, followed by the combined treatment between $T_{5}$ treatment combined with micro-nutrients at $150 \mathrm{ppm}$ (279 and $284 \mathrm{mg} / 100 \mathrm{~g}$ f.w.) in the first and second seasons, respectively. On the contrast, the lowest values of this parameter were gained by $T_{1}$ (control.) combination, especially those received no micro-nutrients sprays in the two seasons.

\section{Leaf total phenols contents:}

Data in Table (11) illustrated that, all fertilization treatments decreased total phenols content in leaves of roselle plants when compared with control, especially $\mathrm{T}_{2}$ (R.D. chemical NPK) as it scored (160 and $147 \mathrm{mg} / 100 \mathrm{~g}$ f.w.) followed ascendingly by $\mathrm{T}_{5}$ (30 $\mathrm{m}^{3}$ compost/fed + bio) as it scored (162 and $149 \mathrm{mg} / 100 \mathrm{~g}$ f.w.) in both seasons. Moreover, all concentration of micronutrients treatments decreased this parameter, especially the highest concentration (150 ppm) sprayed plants in both seasons.

As for the interaction effect between fertilization treatments and micro-nutrients treatments, data in Table (11) reveal that, the lowest values of total phenols content (149 and $131 \mathrm{mg} / 100 \mathrm{~g}$ f.w.) of roselle leaves were recorded by $\mathrm{T}_{2}$ treatment combined with micro-nutrients at $150 \mathrm{ppm}$, followed ascendingly by the combined treatment between $\mathrm{T}_{5}$ treatment and micro-nutrients at 150 ppm (151 and $134 \mathrm{mg} / 100 \mathrm{~g}$ f.w.) in the first and second seasons, respectively. On the contrast, the highest values of this parameter were resulted by $\mathrm{T}_{1}$ (control) combined with no micro-nutrients sprays (181 and 178 $\mathrm{mg} / 100 \mathrm{~g}$ f.w.) in the first and second seasons, respectively. The remained treatments occupied an intermediate position between the abovementioned treatments in the two seasons.

\section{Leaf Fe, Zn and Mn content:}

Data in Table (12) reveal that the highest leaf $\mathrm{Fe}, \mathrm{Zn}$ and $\mathrm{Mn}$ content of roselle plants were obtained by $\mathrm{T}_{2}$ (R.D. chemical NPK), followed by $\mathrm{T}_{5}$ ( $30 \mathrm{~m}^{3}$ compost/fed+ bio) in 


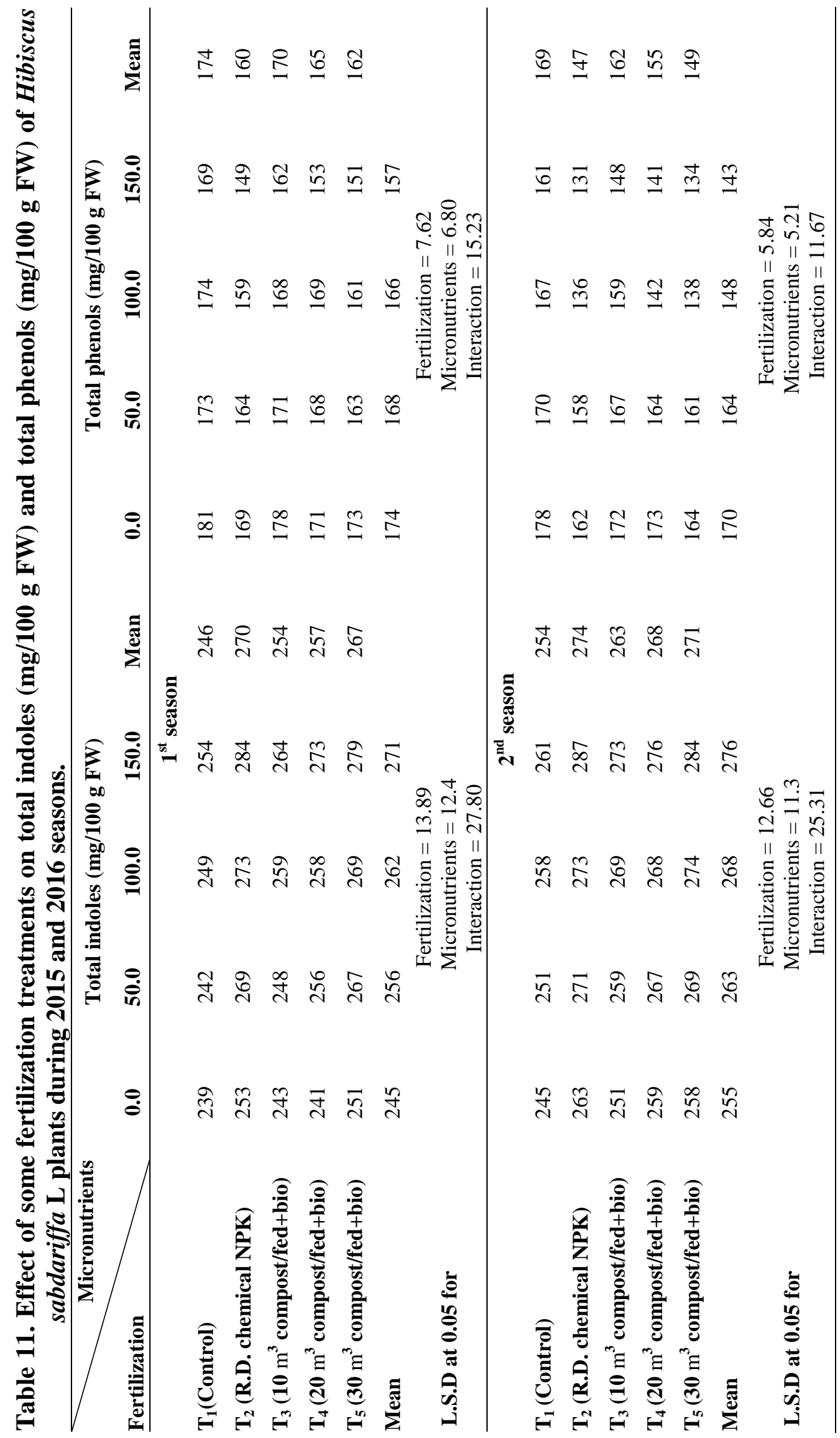




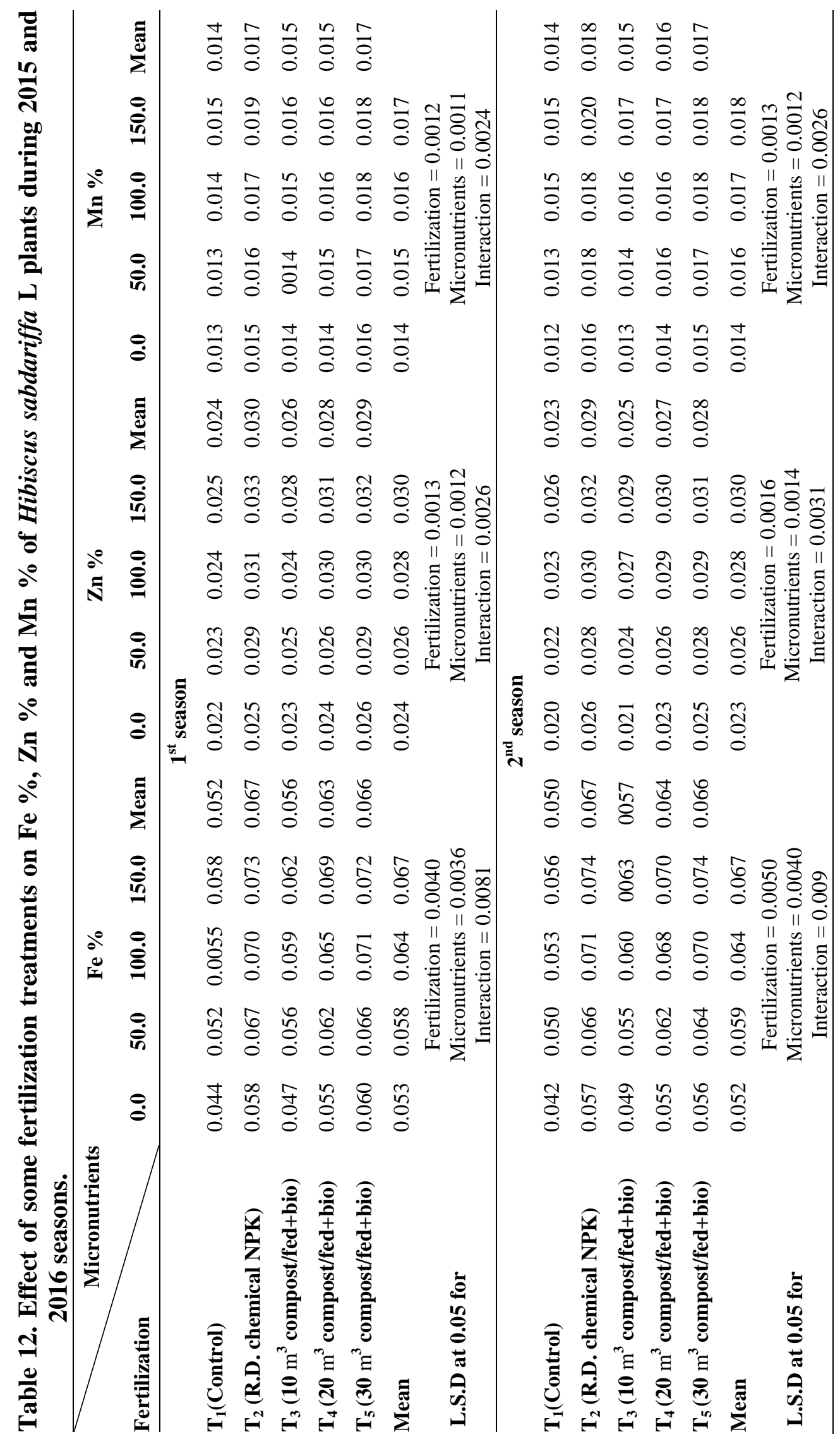


both seasons. Also, all concentration of micro-nutrients increased leaf $\mathrm{Fe}, \mathrm{Zn}$ and $\mathrm{Mn}$ content, particularly the highest concentration in both seasons. Concerning the interaction effect between fertilization and micro-nutrients treatments, data in Table (12) show that the greatest leaf Fe, $\mathrm{Zn}$ and Mn content of roselle plants were obtained by $\mathrm{T}_{2}$ treatment combined with micronutrients at $150 \mathrm{ppm}$, followed by the combined treatment between $\mathrm{T}_{5}$ and micronutrients at $150 \mathrm{ppm}$ in both seasons. The differences between the abovementioned combined treatments were not significant in both seasons. On the reverse, the lowest values of this parameter were gained by $T_{1}$ (control) combination, especially those received no micro-nutrients sprays in the two seasons.

The aforementioned results of fertilization concerning chemical constituents are in parallel with those obtained by Abou El-Ghait et al. (2012) on indian fennel, El-Gendy et al. (2012) on roselle plants, , Mohamed et al. (2012) on Stevia rebaudiana, Amran (2013) on Pelargonium graveolens, El-Khyat (2013) on Rosmarinus officinalis, Sakr et al. (2014) on roselle plants, Youssef (2014) on roselle plants and Ghatas and Abdallah 2016. illustrated that, fertilize Echinacea purpurea plants with $75 \%$ chemical fertilizer (NPK) + 10 ton compost/fed + bio fertilizer (nitrobein + phosphorein) in combination with some micro-nutrients (Zn or B each at 100 ppm) as foliar spray to enhance the chemical composition of plant. Whereas, the abovementioned results of micro-nutrients are nearly similar to those obtained by Gomaa (2008) on Hibiscus sabdariffa, Youssef (2009) on rosemary plant, Amran (2013) on Pelargonium graveolens, ElKhyat (2013) on Rosmarinus officinalis, Youssef (2014) on Echinacea purpurea and Ghatas and Mohamed (2018) demonstrated that, spray Cymbopgon citruts plants with 150ppm $\mathrm{Fe}+\mathrm{Mn}+\mathrm{Zn}$ four times a year to resulted highly increments of $\mathrm{N}, \mathrm{P}, \mathrm{K}$, total carbohydrate $\mathrm{Fe}, \mathrm{Zn}$ and $\mathrm{Mn}$ content of this plant.
The obtained results of this study may be due to the role of fertilization and micronutrients in growth and development of the plants; where the use of $\mathrm{N}$-fixing bacteria (nitrobein) as a bio-fertilizer product containing nitrogen fixing bacteria, e.g. Azotobacter and Azospirillum was found to have not only the ability to fix nitrogen but also to release certain phytohormones of cytokinins, gibberellins and auxins which could enhance plant growth through absorption of nutrients and so on enhancing photosynthesis process Hegde et al. (1999). Microorganisms used as bio-fertilizers may affect the integrity of growing plants by one mechanism or more such as nitrogen fixation production of growth promoting substances or organic acids, enhancing nutrients uptake or protection against plant pathogens Hawaka (2000). Moreover, when organic manures (compost) added as fertilizer, it led to decrease soil $\mathrm{pH}$ which in turn increasing solubility of nutrients for plant uptake, in some cases organic materials may act as low release fertilizer. Recently, on the way of sustainable agriculture with minimum effects, the use of organic manures (compost or chicken manure, ... etc) as natural soil amendments is recommended to replace the soluble chemical fertilizers. They improve the structure of weak-structured sandy soils and increase their water holding capacity. Also, they improve soil fertility, and stimulate root development, induce active biological conditions and enhancing activities of micro-organisms especially those involved in mineralization Suresh et al. (2004). Furthermore, to interpret and evaluate the effect of chemical fertilization concerned in this study, on augmenting the different tested vegetative growth parameters, yield component parameters and chemical constituents of roselle plants. It is important to refer to the physiological roles of nitrogen, phosphorus and potassium in plant growth and development. Such three macronutrient elements are the common elements usually included in fertilizers. Plant supplement with these macronutrients in form of fertilizers is necessary because the 


\section{A.O. Gomaa et al.}

soil is usually in deficient of them due to plant removal leaching or they are not readily available for plants. Therefore, such addition of well-balanced NPK fertilization quantities insured production of high productivity and chemical constituents of roselle plants.

For adequate plant growth and production, micronutrients are needed in small quantities in balance of macronutrients. However, their deficiencies cause a great disturbance in the physiological and metabolic processes in the plant. Plants normally take up nutrients from soils through their roots although nutrients can be supplied to plants as fertilizers by foliar sprays (Baloch et al., 2008). Moreover, activates micro-nutrients, especially $\mathrm{Fe}, \mathrm{Zn}$ and $\mathrm{Mn}$ act either as metal components of various enzymes or as functional, structural, or regulatory cofactors. Thus, they are associated with saccharide metabolism, photo-synthesis and protein synthesis Marschner (1997). Therefore, sufficient amount of these nutrients in the plant is necessary for normal growth, in order to obtain satisfactory yield (Yassen et al., 2010). So, micronutrients such as Fe, Zn and Mn have important roles in growth and chemical composition roselle plant.

Consequently, it is preferable to treat roselle plants with the combined treatment between $T_{2}$ recommended dose of chemical fertilizer or $T_{5} 30 \mathrm{~m}^{3}$ compost/fed + bio fertilizer (nitrobein + phosphorein + potassiumag) combined with $\mathrm{Fe}+\mathrm{Mn}+\mathrm{Zn}$ at $150 \mathrm{ppm}$ for enhancing growth and productivity of this plants.

\section{REFERENCES}

A.O.A.C. (1980). Official Methods of Analysis, $12^{\text {th }}$ Ed. Association of official analysis chemists: Washington, D.C., USA.

A.O.A.C. (1990). Official Methods of Analysis (15 ${ }^{\text {th }}$ Ed.). Association of Official Analytical Chemists, Washington, DC, USA.
Abou El-Ghait, E.M.; Gomaa, A.O.; Youssef, A.S.M.; Atiea, E.M. and AbdAllah, W.H. (2012). Effect of sowing dates, bio, organic and chemical fertilization treatments on growth and production of Indian fennel under north Sinai conditions. Bull. Fac., Cairo Univ., 63:52-68.

Ahmed, M. and Kibret, M. (2014). Mechanisms and applications of plant growth promoting rhizobacteria: Current perspective. J. King Saud Univ. Sci., 26:1-20.

Amran, K.A.A. (2013). Physiological Studies on Pelargonium graveolens L. Plant. Ph.D. Thesis, Fac. Agric., Moshtohor, Benha Univ., Egypt.

Baloch, O.B.; Chacar, O.I. and Tareen, M.N. (2008). Effect of foliar application of macro and micronutrients on production of green chilies (Capcicum annuum L.). J. Agric. Tech., 4(2):177-184.

Black, C.A., Evans, D.O.; Ensminger, L.E. White, J.L.; Clark, F.E. and Dinauer, R.C. (1982). Methods of Soil Analysis. part 2. Chemical and microbiological properties. $2^{\text {nd }}$ Ed. Soil Sci., Soc. of Am. Inc. Publ., Madison, Wisconsin, U. S.A.

Chapman, H.D. and Paratt, P.F. (1961). Methods of Soil, Plants and Water Analysis. Univ. California, Div. Agric. Sci., 314p.

Diab, M.A. (1968). The chemical Composition of Hibiscus sabdariffa, L. M.Sc. Thesis, Fac. Agric., Cairo Univ.

Du, C.T. and Francis, F.J. (1973). Anthocyanins of roselle. Amherst, Mass. J. Food Sci., 38(5):310-312.

Duke, I.A. (1979). Ecosys rematic data on economic plants Ouart. J. Crude Drug. Res., 17(3-4):91-110.

El-Gendy, A.S.H.; Said-Al Ahl, H.A.H. and Mahmoud, A.A. (2012). Growth, productivity and chemical constituents of roselle (Hibiscus sabdariffa L.) plants as influenced by cattle manure and 
biofertilizers treatments. Australian J. of Basic and Applied Science, 6(5):1-12.

El-Gendy, A.S.H.; Said-Al Ahl, H.A.H.; Mahmoud, Abeer A. and Mohamed, Hanaa F.Y. (2013). Effect of nitrogen sourses, bio-fertilizers and their interaction on the growth, seed yield and chemical composition of guar plants. Life Science Journal, 10(3): 389402.

El-Khyat, L.A.S. (2013). Effect of Chemical and Bio-fertilizer on Growth and Chemical Composition of Rosemary Plants. M.Sc. Thesis, Fac. Agric. Moshtohor, Benha Univ.

Fasoyiro, S.B.; Ashyaye, O.A.; Adeola, A. and Samuel, F.O. (2005). Chemical and storability of fruit flavoured (Hibiscus sabdariffa) drinks. World J. Agric. Sci., 1:165-168.

Ghatas, Y.A.A. and Abdallah, W.H. (2016). Effect of Some Fertilization and MicroNutrients Treatments on Growth and Chemical Constituents of Echinacea purpurea plant: J. Plant Production, Mansoura Univ., 7(7):709-719.

Ghatas, Y.A.A. and Mohamed, Y.F.Y. (2018). Influence of Mineral, Micronutrients and Lithovit on Growth, Oil Productivity and Volatile Oil Constituents of Cymbopogon citruts L. Plants: Middle East Journal of Agriculture Research, 7:162-174.

Glick, B.R. (2003). Plant growth promoting bacteria. In: Glick, B.R. and J.J. Pasternak (eds.), Molecular BiologyPrinciples and Applications of Recombinant DNA, pp: 436-54. ASM Press, Washington DC, USA.

Gomaa, A.O. (2008). Effect of tryptophan, $\mathrm{Fe}, \mathrm{Zn}$, and $\mathrm{Mn}$ foliar application on growth, productivity and chemical composition of roselle plants. J. Biol. Chem.Environ.Sci., 3(1):771-790.

Hassan, F. (2009). Response of Hibiscus sabdariffa L. plant to some biofertilization treatments. Annals
Agric. Sci. Ain Shams Univ. Cairo., 54(2):437-446.

Hawaka, F.I.A. (2000). Effect of using single and composite inoculation with Azospirillum brasilense, Bacillus megatherium var. Phosphaticum and Glomus macrocarpus for improving growth of Zea mays. J. Agric. Sci., Mansoura, Egypt, 32(12):239-252.

Hegde, D.M.; Dwivedi, B.S. and Sudhakara Babu, S.S. (1999). Biofertilizers for cereal production in India. A review. Ind. J. Agric. Res., 69(2):73-83.

Herbert, D.; Phipps, P.J. and Strange, R.E. (1971). Determination of total carbohydrates, Methods in Microbiology, 5 (8):290-344.

Horneck, D.A. and Hanson, D. (1998). Determination of potassium and sodium by flame Emission spectrophotometry. In hand book of reference methods for plant analysis, e.d Kolra, Y.P. (ed), 153155.

Horneck, D.A. and Miller, R.O. (1998). Determination of total nitrogen in plant hand book of reference methods for plant analysis, (ed) Kolra,Y.P., 73.

Hucker, T. and Catroux, G. (1980). Phosphorus in sewage ridge and animal's wastes slurries. Proceeding ofthe EEC Seminar, Haren (Gr): Gromingen Netherlands 12, 13 June.

Jackson, M.L. (1973). Soil Chemical Analysis. Prentice-Hall of Indian Private, New Delhi.

Kirby, R.H. (1963). Vegetable, Fibers Ed by Prof. Nicholes, Pallman pp. 29-31. Inter-Science Publishe Inc. New York.

Marschner, H. (1997). Mineral Nutrition of Higher Plants. Second Printing, Academic press INC. San Diego, pp: 889.

Ministry of Agriculture and Land Reclamation (2002). Bulletin of roselle. The Central Administration for 


\section{A.O. Gomaa et al.}

Agricultural Extension, Agricultural Research Center, 545: 3-15.

Mohamed, S.M.; Abou El-Ghait, E.M.; Youssef, A.S.M.; Khalil, A.M.M. and Attia, K.E. (2012). Effect of irrigation rate and some fertilization treatments on vegetative growth and chemical composition of Stevia rebaudiana. Annals of Agric. Sci., Moshtohor, 50(4):435-446.

Naguib, N.Y.M. (2011). Organic vs chemical fertilization of medicinal plants: a concise review of researches. Adv. Environ. Biol., 5(2): 394-400.

Perry, I.M. (1980). Medicinal Plant of East and Southwest Assia, MID, Press, Cambridge.

Sakr, W.R.A.; Elbagoury, H.M.; Sidky, M.A. and Ali, S.A. (2014). Production of Organic Roselle by Natural Minerals and Biofertilizers: American-Eurasian J. Agric. \& Environ. Sci., 14(10):985-995.

Sanyo, K. (1981). Food coloring agent from Hibiscus flower pupl co. L T.D., dap Kaki, Tokyo, Japan, 18: 141: 358 (Chem abstract vol. 96, 1988).

Shahram, S. and Ordookhani, K. (2011). Organic and bio fertilizers as a good substitute for inorganic fertilizers in medicinal plants farming. Australian Journal of Basic and Applied Sciences, 5(12):1330-1333.

Snedecor, G.W. and Cochran, W.G. (1989). Statistical Methods. $8^{\text {th }}$ Ed., Iowa State Univ., Press, Iowa,U.S.A.
Suresh, K.D.; Sneh, G.; Krishn, K.K. and Mool, C.M. (2004). Microbial biomass carbon and microbial activities of soils receiving chemical fertilizers and organic amendments. Arch. Agron. Soil Sci., 50:641-647.

Yassen A.A.; El-Nour, E.A.A. and Shedeed, S. (2010). Response of wheat to foliar spray with urea and micronutrients. J. Amer. Sci., 6(9):14-22.

Youssef, A.S.M. (2009). Effect of some amino acids and mineral nutrients treatments on growth and productivity of rosemary plant (Rosmarinus officinalis, L.). Annals of Agric. Sc., Moshtohor, 47(1):133-148.

Youssef, A.S.M. (2014). Influence of some amino acids and micro-nutrients treatments on growth and chemical constituents of Echinacea purpurea plant: J. Plant Production, Mansoura Univ., 5(4):527-543.

Youssef, A.S.M.; Mady, M.A. and Ali, M.M.E. (2014). Partial substitution of chemical fertilization of roselle plant (Hibiscus sabdariffa L.) by organic fertilization in presence of ascorbic acid: J. Plant Production, Mansoura Univ., 5(3):475-503.

Zheljazkov, V.D. and Warman, P.R. (2004). Source-separated municipal solid waste compost application to Swiss chard and basil. J. Environ. Qual., 33:542-552.

\footnotetext{
تأثير بعض معاملات التسميد على نمو وانتاجية والمحتوى الكيماوى لنبات الكركدية

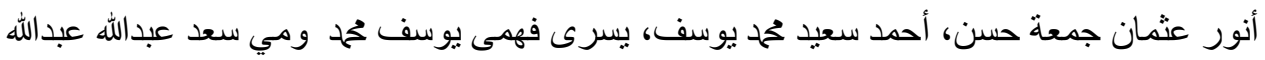

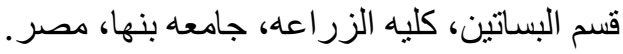

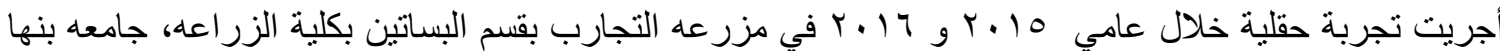

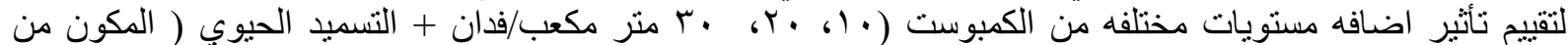

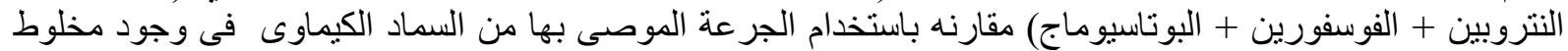

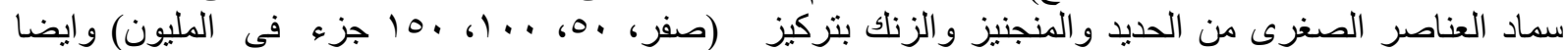

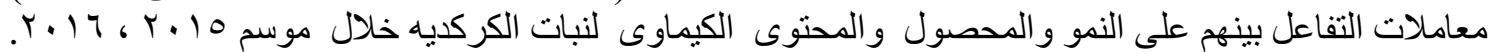




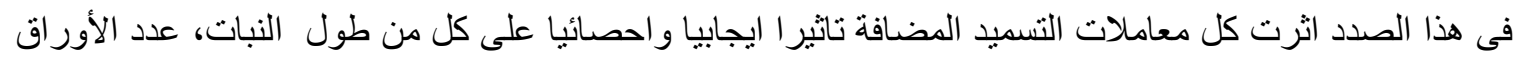

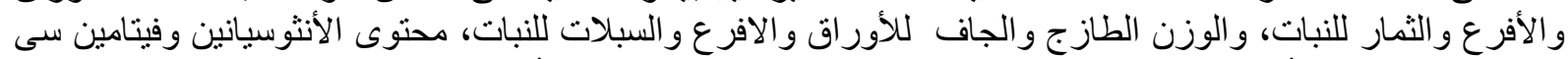

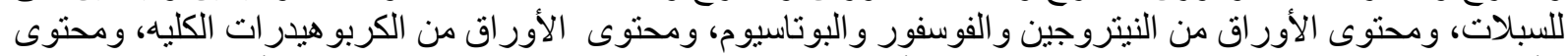

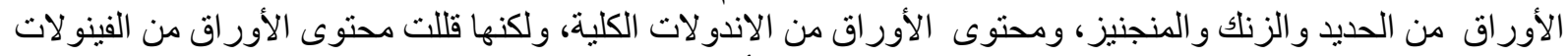

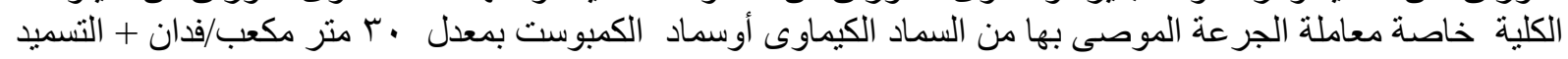

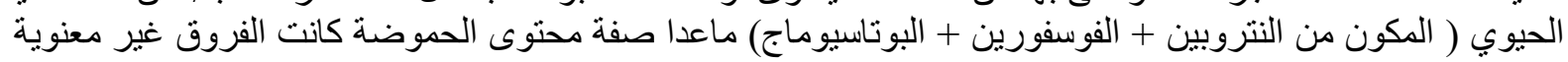

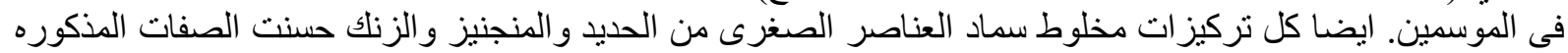

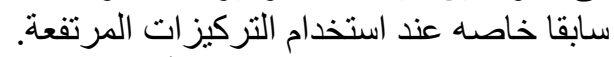

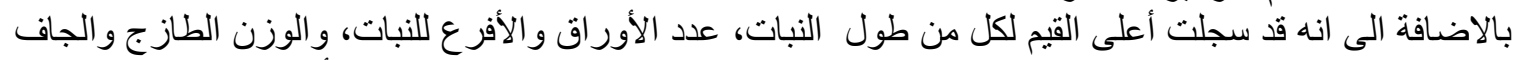

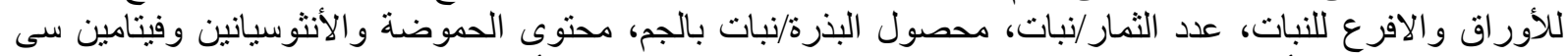

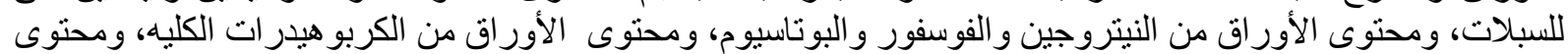

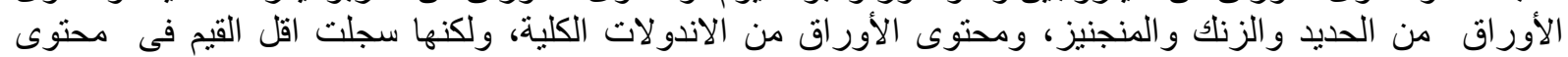

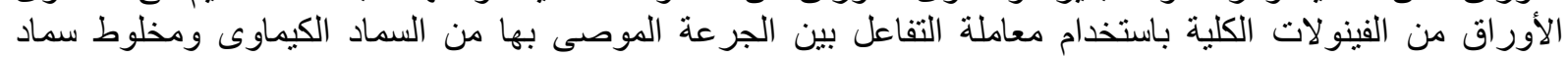

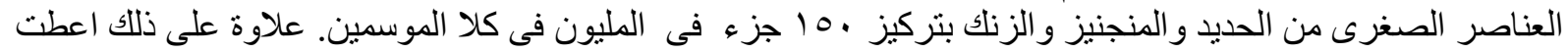

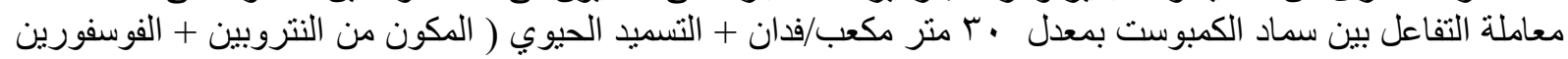

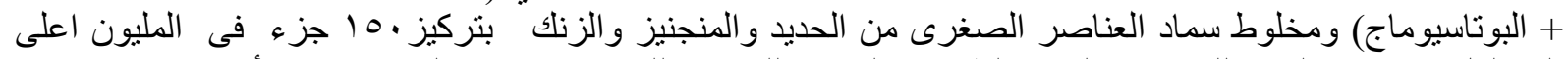

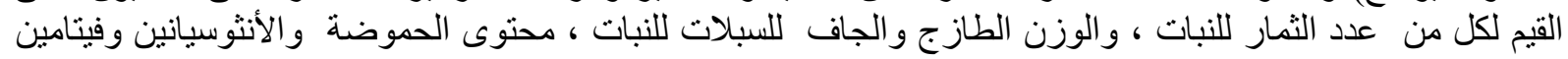

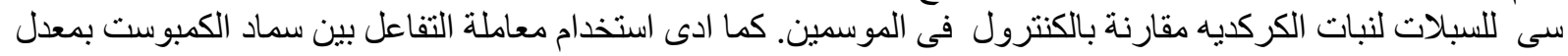

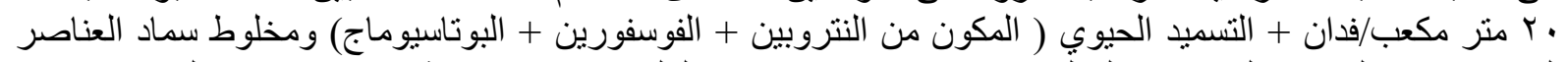

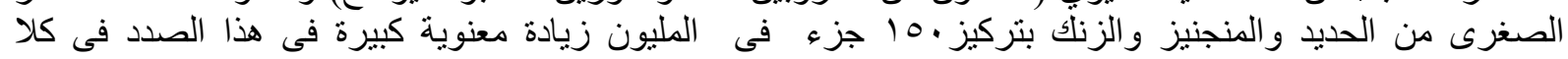

وبناء علي ذللك يفضل معاملة نبات الكركديه بالجر عة الموصى بها من السماد الكيماوى او معاملة التداخل بين معاملة الموسمين.

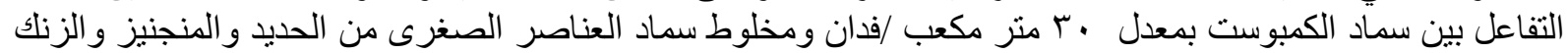
بتركيز •10 جزء في المليون لتحسين وزياده النمو وانتاجية هذان النبات. 